\title{
IODP Expedition 302, Arctic Coring Expedition (ACEX): A First Look at the Cenozoic Paleoceanography of the Central Arctic Ocean
}

\author{
by Jan Backman, Kathryn Moran, David McInroy, \\ and the IODP Expedition 302 Scientists
}

doi:10.2204/iodp.sd.1.02.2005

\section{Introduction}

The behavior and influence of the Arctic Ocean throughout the course of the global Cenozoic climate evolution have been virtually unknown. Only the uppermost few meters of the Arctic's sediment record, representing Holocene and late Pleistocene times, have been retrieved from ridges through a limited number of short piston, gravity, and box cores. Even less of the thick sediment sequences, $\sim 6 \mathrm{~km}$ in the Canada Basin and $\sim 3 \mathrm{~km}$ in the Nansen Basin (Grantz et al., 1990; Jokat et al., 1995), resting on the Arctic Ocean's abyssal plains, have been cored. Prior to the Arctic Coring Expedition (ACEX), information on Neogene or Paleogene conditions in the central Arctic was limited to a 1.6-m interval in a 3.6-m-long T-3 gravity core raised from the Alpha Ridge (Clark, 1974), providing the sole evidence for marine conditions no older than the middle Eocene in the central Arctic (Bukry, 1984).

\section{Objectives}

The primary scientific objective of ACEX, the first mission-specific platform (MSP) expedition in the history of scientific deep-sea drilling, was the recovery of a 400-450-m-thick, continuous post-Paleocene stratigraphic section from the central part of the Lomonosov Ridge between $87^{\circ} \mathrm{N}$ and $88^{\circ} \mathrm{N}$. This unique opportunity to acquire first-order knowledge about the paleoceanographic history of the central Arctic Ocean also represented a fundamental step toward a quantitative description of Cenozoic global change that incorporates the influence of the Arctic Ocean.

Specific paleoceanographic objectives were to

- understand the history of ice rafting and sea ice

- study local versus regional ice-sheet development

- determine the density structure of Arctic

Ocean surface waters, the nature of the North

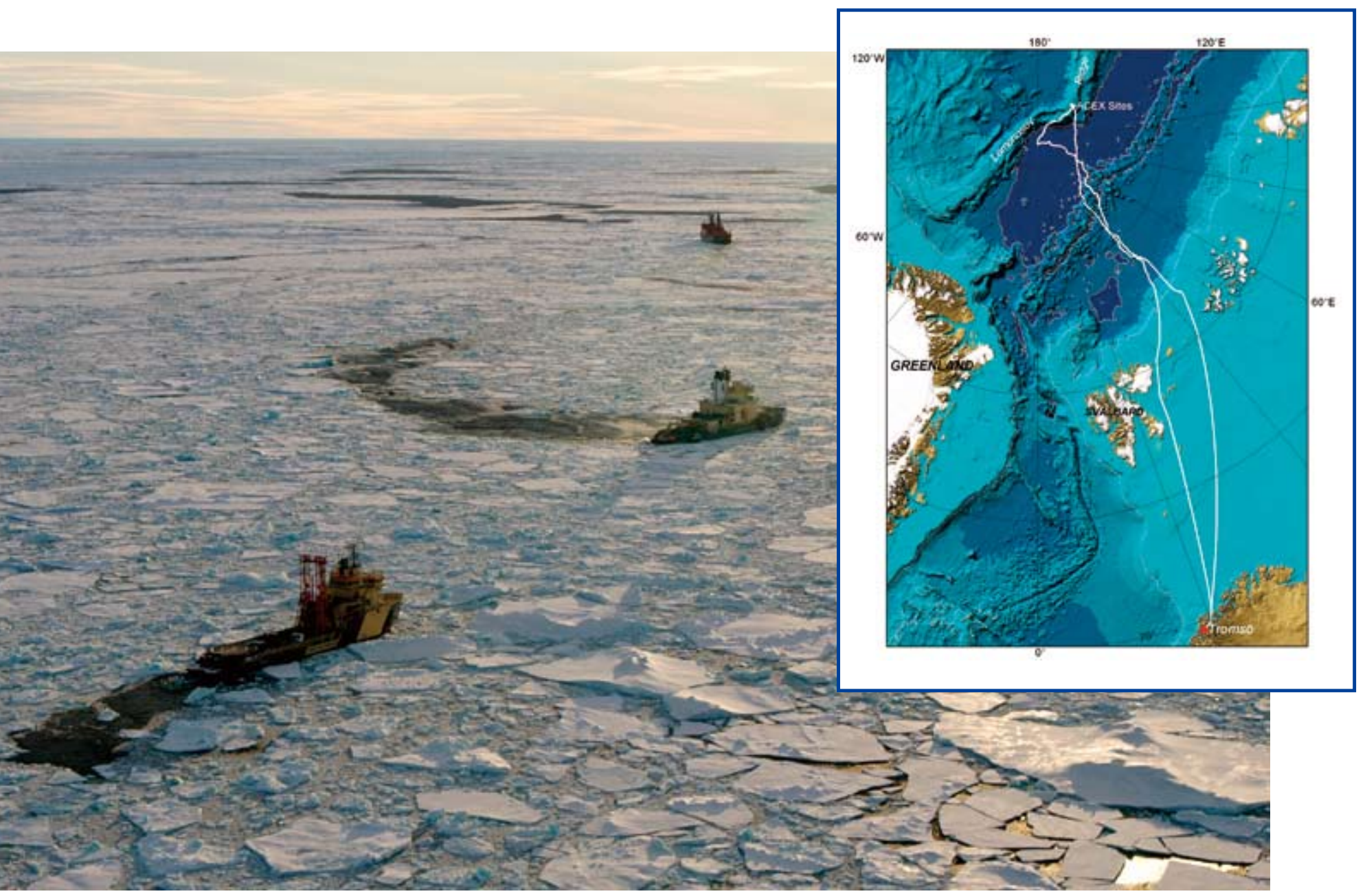


Atlantic conveyor, and onset of Northern Hemisphere glaciation

-determine the timing and consequences of the opening of the Bering Strait

- study the land-sea links and the response of the

Arctic to Pliocene warm events

- investigate the development of the Fram Strait and deep-water exchange between the Arctic Ocean, the Greenland-Iceland-Norwegian Seas, and the world ocean

-determine the history of biogenic sedimentation.

Sampling of the underlying bedrock provides an excellent opportunity to decipher the tectonic history of the Lomonosov Ridge and the formation of the Eurasian Basin. The tectonic objectives were focused on ridge evolution. If proven to be a continental fragment, the ridge represents truly unique global information on the relative strength of continental and oceanic lithosphere. Specific tectonic objectives for drilling on the Lomonosov Ridge were to

-investigate the nature and origin of the Lomonosov Ridge by sampling the oldest rocks below the regional unconformity to establish the pre-Cenozoic environmental setting of the ridge

- study the history of rifting and the timing of tectonic events that affected the ridge.

\section{Three Icebreakers and a Helicopter}

ACEX began in Tromsø, Norway on 7 August 2004 and returned to Tromsø on 13 September (Fig. 1). The biggest challenge was maintaining the drillship's location while drilling and coring in heavy sea ice over the Lomonosov Ridge. The sea-ice cover moved at up to 0.5 knots with the Transpolar Drift and was affected by local responses to wind, tides, and currents.

Plans for this first-ever event were carefully crafted over several years and included a fleet of three Arctic-class ships: a drilling vessel, the Vidar Viking, that remained on a fixed location while suspending more than $1600 \mathrm{~m}$ of drillpipe through the water column and into the underlying sediments; a Russian nuclear icebreaker, the Sovetskiy Soyuz; and the diesel-electric icebreaker Oden. The Sovetskiy Soyuz and the Oden protected the Vidar Viking by breaking upstream floes into small bergy bits to allow the Vidar Viking to stay on position continuously to drill and recover the sediment cores.

This strategy proved to be a great success. Planners had predicted that the fleet could maintain the drillship's station for up to two full days, yet the station-keeping ability turned

Figure 1. Arctic Expedition vessels in low sun with an expedition trackchart map. Bottom left: Vidar Viking, center: Icebreaker Oden, top: Icebreaker Sovetskiy Soyuz. out to be much more successful than anticipated. The three ships coordinated their efforts through a central fleet manager, and the ice management defense strategies were continuously updated, sometimes on a minute-to-minute basis, with information from a full-time ice and weather forecast team aboard the Oden and the Sovetskiy Soyuz.

The fleet kept the Vidar Viking on location in $90 \%$ cover of multi-year ice for up to nine consecutive days-a landmark feat that if repeated will allow scientists to continue to explore this least known of our oceans through scientific ocean drilling for many years to come.

The scientific party consisted of seventeen scientists in the offshore group and an additional fourteen scientists in the onshore group. Eleven scientists were stationed aboard the Oden, where laboratory facilities were available. Three scientists (co-chief, stratigraphic correlator, geochemist) were on the drillship during drilling. Shift changes of that three-person group and transport of core-catcher samples to the Oden lab occurred routinely twice per day via short helicopter flights between the Oden and the Vidar Viking. Coring operations were conducted by Seacore, Ltd., using a specially built drill rig for the Vidar Viking and coring tools were provided by the British Geological Survey (BGS). Only core-catcher samples were split and described on board.

\section{Results}

The ACEX drilling sites lie only a few nautical miles apart between 1200 and $1300 \mathrm{~m}$ water depth near $88^{\circ} \mathrm{N}$, along a single seismic line (AWI-91090; Fig. 2) showing an identical and coherent Cenozoic seismostratigraphy. ACEX drilled five holes at four sites into the Cenozoic sediment drape, and one of the holes penetrated into the underlying sedimentary bedrock. A total of eight advanced piston corer (APC) cores, 110 extended core barrel (XCB) cores and one wash core were obtained at these four sites, yielding a total of $339.1 \mathrm{~m}$ of core, corresponding to $68.4 \%$ recovery. Hole M0002A yielded a recovery of $78.5 \%$ between the mudline and $272 \mathrm{mbsf}$ (middle Eocene). Hole M0004A yielded a recovery of $47.4 \%$ between $265 \mathrm{mbsf}$ and the terminal depth at 427.9 mbsf (Campanian). Despite the limitations associated with these recovery gaps, ACEX has provided, for the first time, a fairly long record of Cenozoic sedimentation from the central Arctic Ocean, permitting us to move away from pure speculation about the Arctic's Cenozoic paleoenvironmental evolution.

\section{Major Lithologies of the Cenozoic and Late Cretaceous Arctic Ocean}

The four neighboring ACEX drilling sites are treated as a single stratigraphic section. Four lithologic units are defined on the basis of the visual core description, smearslide analysis, total organic carbon (TOC), and x-ray diffraction (XRD) measured in core-catcher samples. Color changes are also used to define lithologic units, although 
color changes do not always coincide with mineralogical and textural changes, suggesting a strong diagenetic influence on color banding in the sediments. Unit $1(0-$ $220 \mathrm{mbsf}$, Holocene to middle Eocene) is characterized by soft terrigenous silty clays with occasional biogenic carbonate only in the upper 15-18 m. Unit 2 (220-314 mbsf, middle Eocene) is a dark gray, mud-bearing, biosiliceous ooze, with submillimeter-scale light and dark laminations throughout. The biosilica is composed chiefly of diatoms, ebridians, and silicoflagellates. Radiolarians occur in only three core-catcher samples. Isolated small pebbles, interpreted to be dropstones from floating sea ice, were observed to nearly $240 \mathrm{mbsf}$. Seasonal sea ice thus existed from the middle Eocene onward. Data on the development of the Arctic's perennial sea-ice cover remain to be analyzed. Unit 3 (314-405 mbsf, lower Eocene to upper Paleocene) is composed of dark gray clays grading into dark olive-gray silty clays with depth. The oldest biosilica appears in the lower Eocene. Sediments are commonly laminated, and pyrite nodules are common in several cores. The Paleocene -Eocene boundary and the carbon isotope excursion (CIE) interval were partially recovered. Unit 4 (425-428 mbsf, UpperssCretaceous) is composed of dark olive-gray clayey mud. A sandstone fragment was recovered. The sequence of agglutinated foraminiferal assemblages in the lower Eocene through Upper Cretaceous sediments can be used to reconstruct shallow-water marine environments from prodeltaic or inner neritic to uppermost bathyal environments.

\section{Biostratigraphy and Sedimentation Rates}

Micropaleontological investigations included the analysis of calcareous nannoplankton, diatoms, silicoflagellates, ebridians, radiolarians, calcareous and agglutinated benthic

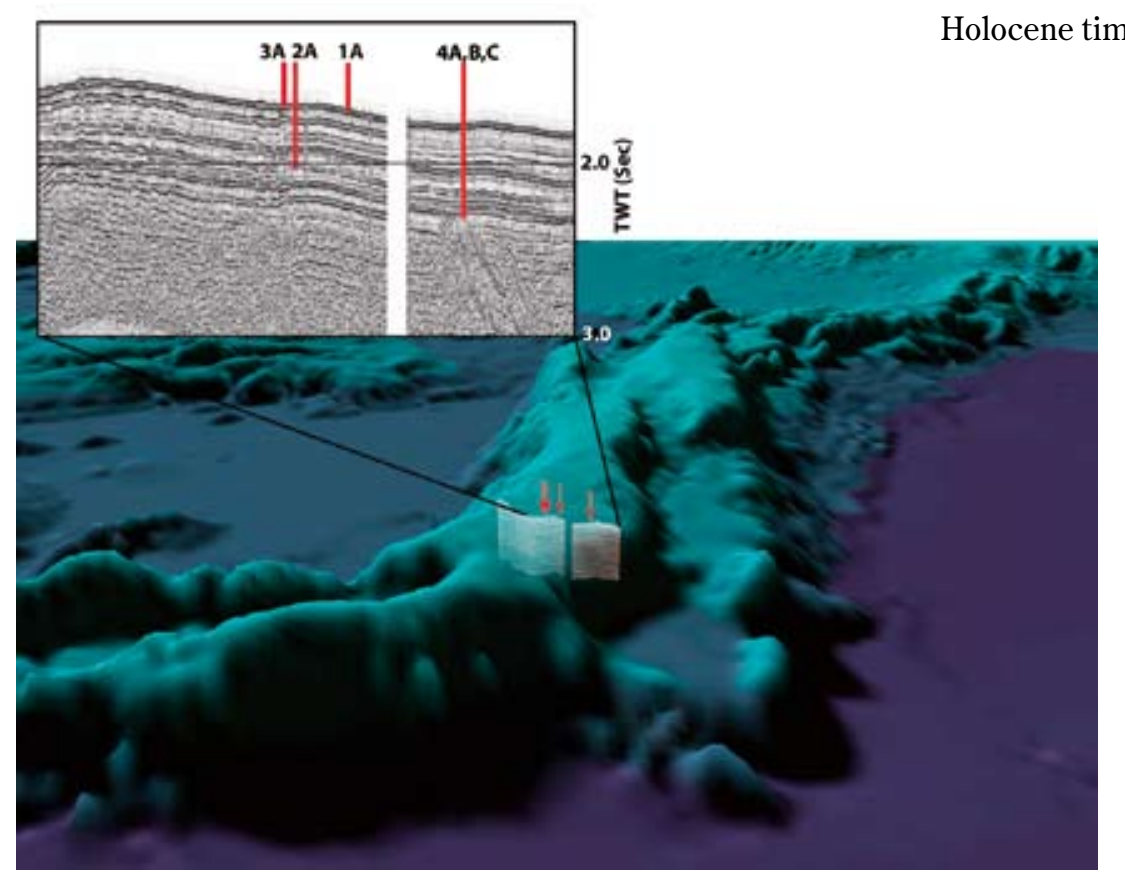

Figure 2. Bathymetry and site locations/penetration depths on reflection seismic line AWI 91090. foraminifera, planktonic foraminifera, ostracodes, organicwalled dinoflagellate cysts (dinocysts), other palynomorphs, and fish remains.

Siliceous microfossils, notably diatoms, silicoflagellates, and ebridians, are abundant and well preserved in the middle Eocene interval. Planktonic foraminifera, calcareous benthic foraminifera, and ostracodes are rare in the Pleistocene through Miocene intervals and absent in the older sediments. Agglutinated benthic foraminifera are scarce overall but are locally abundant and well preserved in the Campanian and Paleocene to lower Eocene intervals. Organic-walled dinoflagellate cysts (dinocysts) are patchy in the Miocene to Pleistocene intervals but are abundant and well preserved in the Cretaceous and Paleogene intervals. Other palynomorphs, notably pollen, spores, and remains of aquatic algae (chlorophytes), are common in most intervals. An acme of remains of the hydropterid fern Azolla marks the basal middle Eocene.

Preliminary age assessment is based principally on dinocyst data and the Azolla event using information on the Paleogene from the Ocean Drilling Program (ODP) Site 913B in the Greenland Sea (Eldrett et al., 2004). Additional age information is derived from silicoflagellates and ebridians in the middle Eocene and a few benthic foraminiferal events in the older Paleogene. The stratigraphic sequence ranges in age from the Campanian (basement) to the Holocene. Unconformities or disconformities mark the Cretaceous-Tertiary, the Eocene-Oligocene, possibly the Oligocene-Miocene and the Pliocne-Pleistocene boundaries. The cored sections, represent the early Campanian, the latest Paleocene through middle Eocene, possibly the late Oligocene or early Miocene, the late middle to late Miocene, and part of the Pliocene, Pleistocene, and Holocene time periods.

Biostratigraphic data will be useful in developing the age model for the ACEX sites. Paleomagnetic data are being acquired and will be amalgamated with the biostratigraphic data to provide an age model for the ACEX sites. Among the biostratigraphy, dinocysts provide the bulk of the biostratigraphic data on the Neogene. For the Eocene, diatom and silicoflagellate biostratigraphies are added to the dinocyst data set.

The available biostratigraphic data (Fig. 3) suggest sedimentation rates on the order of 1-3 $\mathrm{cm} \mathrm{ky}^{-1}\left(10-30 \mathrm{~m} \mathrm{My}^{-1}\right)$ during the Pleistocene to middle Miocene and during the middle Eocene to latest Paleocene. Currently, we lack age information for the $\sim 30$-m wide zone separating the two corre- 
sponding stratigraphic intervals. Although the available biostratigraphic data clearly suggest the presence of a major hiatus separating the Neogene and Paleogene deposits, the total extent of this hiatus and its exact location in the stratigraphic column are unknown. Another major hiatus appears to separate the upper Paleocene and underlying Campanian sediments. These data do not support previously held notions about slow, millimeter-scale Plio-Pleistocene sedimentation in the central Arctic Ocean (e.g. Clark et al., 1980, 2000).

The dinoflagellate species Apectodinium augustum is abundant in pyrite-rich mudstones at around $380 \mathrm{mbsf}$, indicating partial recovery of the Paleocene-Eocene thermal maximum (PETM) interval, when the Arctic Ocean must have experienced (summer) surface temperatures on the order of $20^{\circ} \mathrm{C}$.

\section{An Azolla Event in the Middle Eocene}

Dinoflagellate cysts, diatoms, ebridians, and silicoflagellates are common to abundant in the middle Eocene section that includes a spectacular basal layer showing massive occurrences of glochidia and massulae (megaspores) of the fresh-water hydropterid fern Azolla, suggesting strongly reduced surface-water salinity or perhaps even a brief episode of fresh-water conditions at the surface. Zero core recovery over an $\sim 18$-m interval immediately below the Azolla layer makes it impossible to reconstruct the progress of paleoenvironmental changes that culminated in this spectacular event. It is yet unknown if the Azolla spores represent an indigenous signal, indicating fresh to nearly fresh surface water, or if they were transported into a marine Arctic basin from a neighboring fresh-water system; however, the sporadic and rare occurrences of radiolarians in the biosiliceous Eocene deposits suggest that the Arctic's surface water salinities were indeed reduced throughout that interval.

\section{Pore Water: Rhizons, Metals, and Gypsum}

One growing legacy of scientific ocean drilling is the realization that sediment sequences represent deep biosphere systems where solids, fluids, and microbes interact over time and space. The crest of the Lomonosov Ridge is no exception, following initial results of Expedition 302. As at other locations (e.g. D'Hondt et al., 2004), this inference comes largely from pore-water profiles (Fig. 4). Pore-water sampling, however, presented a major challenge for Expedition 302. The limited deck space on the Vidar Viking meant that the chemistry laboratory was confined to less than half of a $5.5-\mathrm{m} \times 2.2-\mathrm{m}$ container on the aft deck, and only one person per 12 -hour shift could collect and analyze pore-water samples. The high priority placed on stratigraphic continuity also meant that conventional cutting of whole-round samples was restricted to once every 15 to $20 \mathrm{~m}$ from cores that already had been logged for physical properties.

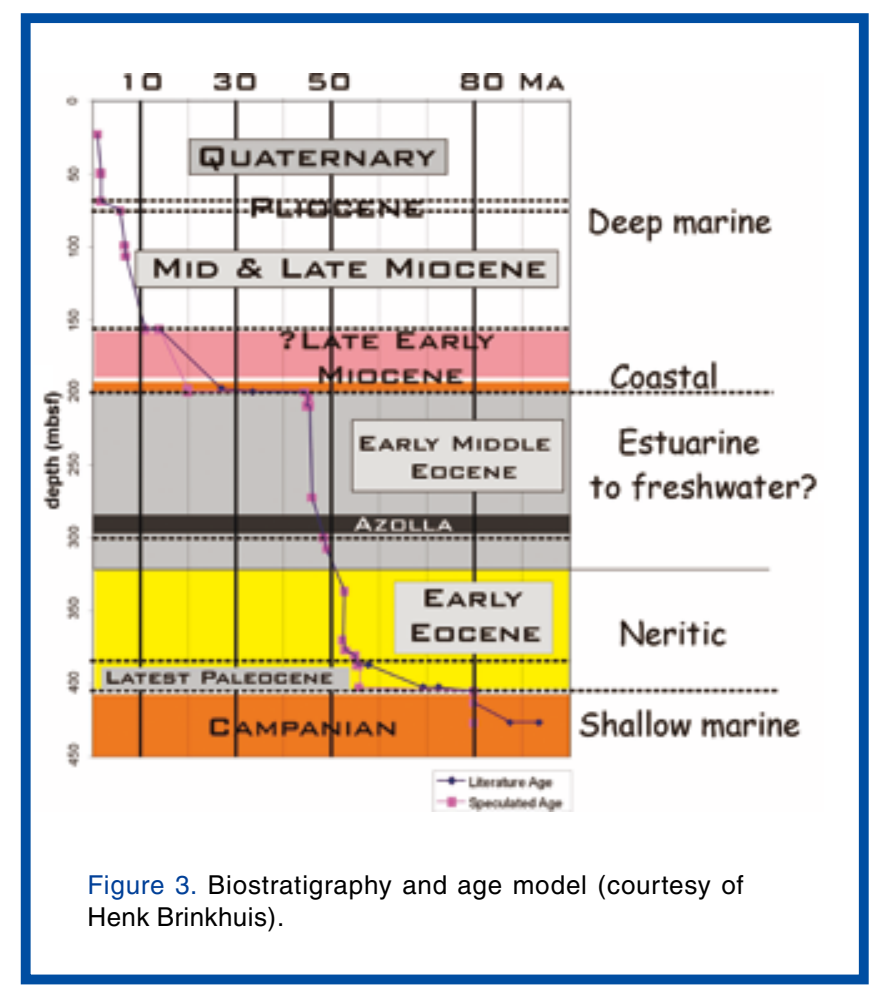

To supplement the whole-round sampling scheme, Expedition 302 instituted a new method for collecting pore water from drill cores. Rhizon samplers are thin tubes made of hydrophilic porous polymer designed to extract water from porous sediment using a vacuum (e.g., Knight et al., 1998; Tye et al., 2003; Seeberg-Elverfeldt et al., submitted). Unlike the traditional squeezing method for obtaining pore water, Rhizon samplers extract water from intact sediment, thereby preserving the sedimentary record. They are also disposable and thus require no cleaning.

The combined use of Rhizon sampling and traditional squeezing provided a sufficient number of pore-water samples to construct fairly detailed profiles of dissolved constituents (see Fig. 4). These profiles are interesting because they shed light on deep biosphere processes integral to central Arctic Ocean history, including manganese cycling and gypsum dissolution.

Chemical analyses of bulk sediment from central Arctic Ocean piston cores have revealed a series of solidphase manganese enrichments (Li et al., 1969; Jakobsson et al., 2000). The new pore-water profiles help to explain these manganese enrichments. Dissolved $\mathrm{Mn}^{2+}$ shows a broad, skewed peak beneath the seafloor, consistent with dissolution of solid-phase $\mathrm{Mn}$ between 10 and $25 \mathrm{mbsf}$, upward diffusion of dissolved $\mathrm{Mn}^{2+}$ toward the seafloor, and reprecipitation of solid-phase $\mathrm{Mn}$ at nominally $2 \mathrm{mbsf}$. The manganese enrichments in sediment probably record non-steady-state diagenesis and changes in the upward flux of dissolved $\mathrm{Mn}$, which may reflect variations in organic supply or bottom-water oxygen content (e.g., Burdige and Gieskes, 1983). 
Pore-water concentrations of dissolved total $\mathrm{S}(\Sigma \mathrm{S})$ and $\mathrm{Ca}^{2+}$ also reveal an important phenomenon. From the seafloor to the top of the dark gray clay interval at $\sim 200 \mathrm{mbsf}$, dissolved $\Sigma \mathrm{S}$ steadily decreases to $8 \mathrm{mM}$, while dissolved $\mathrm{Ca}^{2+}$ increases to $15 \mathrm{mM}$. The decrease in $\Sigma \mathrm{S}$ and a corresponding increase in alkalinity with depth are consistent with sulfate reduction of organic carbon, but only at the top of the dark gray clays. Considering the high organic carbon content of the sediment, one might expect $\Sigma \mathrm{S}$ to decrease to zero instead of to approximately one-third of seawater concentration; however, the dissolution of gypsum, dispersed throughout the dark gray clays, releases $\mathrm{SO}_{4}^{2-}$ and $\mathrm{Ca}^{2+}$ to the pore water.

\section{Other Offshore and Onshore Analyses and Sampling}

The aim of recovering multiple cores across the same stratigraphic intervals for correlating between holes could not be achieved to the extent planned. Material recovered from separate but closely spaced sites allowed a limited amount of correlation, based on physical property data but also aided by high-resolution geochemical measurements of dissolved ammonia, alkalinity, and other pore-water constituents.

The Miocene to Pleistocene interval is characterized by low contents $(<0.4 \mathrm{wt} \%)$ of total organic carbon (TOC), primarily of terrigenous origin, which may be caused by low primary productivity due to sea-ice coverage. The

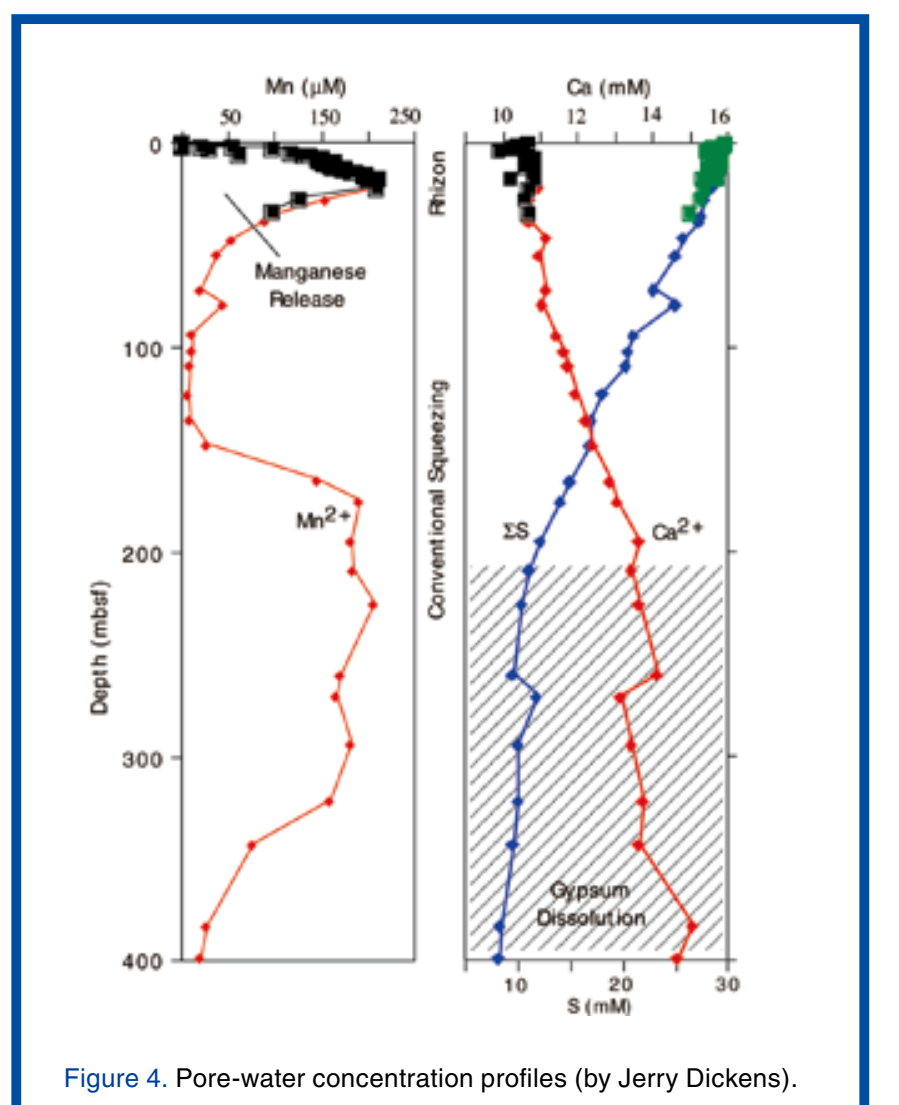

Paleocene to Eocene interval shows TOC values of 1 to $>3 \mathrm{wt} \%$. Increased primary production, increased preservation under suboxic to anoxic conditions, or both have probably caused this enrichment in organic carbon. Sampling for microbiological analyses was conducted to provide estimates of subsurface biomass and for DNA extraction and microbial community characterization. A handful of samples were collected for lipid biomarker analysis.

Petrophysical measurements performed during the offshore component of ACEX included non-destructive, whole-core measurements of bulk density, compressional P-wave velocity, resistivity, magnetic susceptibility, downhole wireline logging, and discrete measurements of shear strength and index properties. Whole-core measurements were made on temperature-equilibrated cores aboard the Vidar Viking using the multi-sensor track (MST). In core sections where Rhizon or whole-round samples were taken for geochemical analyses, the section was run before being temperature equilibrated to ensure that an undisturbed petrophysical record existed for all recovered material. Shear strength was measured using the pocket penetrometer or torvane as the core was being sectioned and prepared for curation, while index property samples were routinely taken from core catchers and analyzed on the Oden. In addition, five in situ temperature measurements were made using both the BGS and the Adara temperature tools.

\section{Acknowledgments}

We thank the IODP and the captains (Jørgen E. Haave, Stanislaw Smith, Tomas Årnell) and crews on the Vidar Viking, the Sovetskiy Soyuz, and the Oden, who made it possible to accomplish the first scientific drilling in the central Arctic Ocean.

\section{IODP Expedition 302 Scientists}

J. Backman (Co-Chief Scientist), K. Moran (Co-Chief Scientist), D. McInroy (Staff Scientist), H. Brinkhuis, S. Clemens, T. Cronin, J. Dickens, F. Eynaud, J. Gattacceca, M. Jakobsson, R. Jordan, M. Kaminski, J. King, N. Koç, N. Martinez, J. Matthiessen, T. Moore, J. Onodera, B. Rea, M. O’Regan, H. Pälike, D. Rio, T. Sakamoto, D.C. Smith, R. Stein, K. St. John, I. Suto, N. Suzuki, K. Takahashi, M. Watanabe, and M. Yamamoto.

\section{Observer}

\section{A. Krylov}

\section{References}

Bukry, D., 1984. Paleogene paleoceanography of the Arctic Ocean is constrained by the middle or late Eocene age of USGS Core Fl-422: evidence from silicoflagellates. Geology, 12:199-201. 
Burdige, D.J., and Gieskes, J.M., 1983. A pore water/solid phase diagenetic model for manganese in marine sediments. Am. J. Sci., 283:29-47.

Clark, D.L., 1974. Late Mesozoic and early Cenozoic sediment cores from the Arctic Ocean. Geology, 2:41-44.

Clark, D.L., Kowallis, B.J., Medaris, L.G., and Deino, A.L., 2000. Orphan Arctic Ocean metasediment clast: local derivation from Alpha Ridge pre-2.6 Ma ice rafting? Geology, 28:1143-1146.

Clark, D.L., Whitman, R.R., Morgan, K.A., and Mackay, S.D., 1980. Stratigraphy and glacial marine sediments of the Amerasian basin, central Arctic Ocean. Spec. Publ.-Geol. Soc. Am., 181:1-57.

D'Hondt, S., Jorgensen, B.B., Miller, D.J., Batzke, A., Blake, R., Cragg, B.A., Cypionka, H., Dickens, G.R., Ferdelman, T., Hinrichs, K.U., Holm, N.G., Mitterer, R., Spivack, A., Wang, G., Bekins, B., Engelen, B., Ford, K., Gettemy, G., Rutherford, S.D., Sass, H., Skilbeck, C.G., Aiello, I.W., Guerin, G., House, C.H., Inagaki, F., Meister, P., Naehr, T., Niitsuma, S., Parkes, R.J., Schippers, A., Smith, D.C., Teske, A., Wiegel, J., Padilla, C.N., and Acosta, J.L., 2004. Distributions of microbial activities in deep subseafloor sediments. Science, 306:2216-2221.

Eldrett, J.S., Harding, I.C., Firth, J.V., and Roberts, A.P., 2004. Magnetostratigraphic calibration of EoceneOligocene dinoflagellate cyst biostratigraphy from the Norwegian-Greenland Sea. Mar. Geol., 204:91-127.

Grantz, A., May, S.D., Taylor, P.T., and Lawver, L.A., 1990. Canada Basin. In Grantz, A., Johnson, L., and Sweeney, J.F. (Eds.), The Geology of North America (Vol. L): The Arctic Ocean Region: Boulder (Geol. Soc. Am.), 379-402.

Jakobsson, M., Løvlie, R., Al-Hanbali, H., Arnold, E., Backman, J., and Mörth, M., 2000. Manganese and color cycles in Arctic Ocean sediments constrain Pleistocene chronology. Geology, 28:23-26.

Jokat, W., Weigelt, E., Kristoffersen, Y., Rasmussen, T., and Schöne, T., 1995. New insights into the evolution of the Lomonosov Ridge and the Eurasian Basin. Geophys. J. Int., 122:378-392.

Knight, B.P., Chaudri, A.M., McGrath, S.P., and Giller, K.E., 1998. Determination of chemical availability of cadmium and zinc in soils using inert soil moisture samplers. Environ. Pollut. (1987), 99(3):293-298.

Li, Y.-H., Bischoff, J., and Mathieu, G., 1969. Migration of manganese in Arctic Basin sediment. Earth Planet. Sci. Lett., 7:265-270.

Seeberg-Elverfeldt, J., Schlüter, M., Feseker, T., and Kölling, M., submitted. A Rhizon in situ sampler (RISS) for pore water sampling from aquatic sediments. Limnol. Oceanogr.
Tye, A.M., Young, S.D., Crout, N.M.J., Zhang, H., Preston, S., Barbosa-Jefferson, V.L., Davison, W., McGrath, S.P., Paton, G.I., Kilham, K., and Resende, L., 2003. Predicting the activity of $\mathrm{Cd}^{2+}$ and $\mathrm{Zn}^{2+}$ in soil pore water from the radio-labile metal fraction. Geochim. Cosmochim. Acta, 67:375-385.

\section{Authors}

Jan Backman, Department of Geology and Geochemistry, Stockholm University, SE-10691 Stockholm, Sweden, e-mail: backman@geo.su.se

Kathryn Moran, Graduate School of Oceanography, University of Rhode Island, Narragansett RI 028821, U.S.A.

David McInroy, British Geological Survey, Murchison House, West Mains Road, Edinburgh EH9 3LA, U.K.

and the IODP Expedition 302 Scientists

\section{Related Weblink}

http://www.ecord.org/exp/acex/302.html

\section{Figure Credits}

Fig. 1 photograph by Martin Jakobsson. 